\title{
ANAESTHESIA AND THE LIVER: HISTORY AND EPIDEMIOLOGY
}

\author{
Michael H.M. DYKes, M.B., B. Chir.*
}

A PROVEn DAMAgING EFFECT of an anaesthetic agent on the human liver is an adverse drug reaction, and must receive its final evaluation by studies, conducted in sick human populations, of both the efficacy and the toxicity of the drug. Such studies fall within the province of the epidemiologist, and must rely on the techniques he has developed for their conduct. MacMahon et al..$^{1,2}$ have divided the "Strategy of Epidemiology" into four steps. First, descriptive epidemiology, or the search for variables associated with a disease, and second, formulation of hypotheses, or the drawing up of tentative theories regarding the most direct causal associations possible between the disease and the variables associated with it. The final two steps, aimed at testing hypotheses, are analytic epidemiology (non-experimental studies), and experimental epidemiology (prospective randomized clinical trials). Non-experimental studies can be of two types, case-control (case-history) studies and cohort studies. In case-control studies, two groups of patients, one affected with the disease under study and the other not so affected, are selected: the incidence of exposure to the suspected causal factor is then compared. In cohort studies, two groups of patients, one of which suffers exposure to the causal factor under study and the other of which does not, are selected. The groups are then observed to determine the proportion of each group that develops the disease under study. These studies may be either retrospective or prospective in nature; case-control studies are of necessity retrospective in nature. The effect of halothane upon the human liver has only been investigated satisfactorily by means of cohort studies.

\section{The EARLy Years: 1848-1912}

As I have recently reviewed this historical era in detail, ${ }^{3}$ I will summarize it here. The first two cases of jaundice and death following the administration of chloroform were reported by Heyfelder in 1848. ${ }^{4}$ Thus, recognition of and concern over hepatic dysfunction and damage, as a complication of anaesthesia and surgery, are as old as the specialty of anaesthesia itself. Interestingly, it is not well known that in 1865 Simpson introduced carbon tetrachloride for use as an inhalation anaesthetic agent. ${ }^{5}$ The drug fell into disuse a decade later, ${ }^{6}$ apparently because of its potent affects upon the cardiovascular system, and not because of any obvious evidence of hepatoxicity.

"Assistant Professor of Anaesthesia at the Beth Israel Hospital, Harvard Medical School, and Anaesthetist, Beth Israel Hospital.

From the Department of Anaesthesia, Harvard Medical School and the Beth Israel Hospital, Boston, Mass. 02215.

Supported in part by Grant GM15904 from the National Institute of General Medical Sciences, United States Public Health Service.

Please address reprint requests to: Beth Israel Hospital, 330 Brookline Avenue, Boston, Mass., 02215, U.S.A.

Canad. Anaesth. Soc. J., vol. 20, no. 1, January 1973

Printed in Canada 
During the first decade of this century, Bevan and Favill ${ }^{7}$ reported 30 isolated case reports of "the late poisonous effects of anesthetics" following both chloroform and diethyl ether. In addition, the experimental laboratory work which established central hepatic necrosis as the typical lesion produced by chloroform in the dog, was conducted. ${ }^{8.9}$ It must be noted, however, that the drug was not administered to the animals in a manner which would constitute acceptable clinical practice today.

Apparently on the basis of the above ancedotal clinical and experimental animal work the Committee on Anesthesia of the American Medical Association ${ }^{10}$ recommended, "the use of chloroform as the ancsthetic for major operations is no longer justifiable," because both clinical and experimental evidence indicated that delayed chloroform poisoning "follows in a by no means inconsiderable percentage of cases." It is unfortunate that the above statement was offered in lieu of even an approximate numerical value for the incidence of the adverse reaction underlying the condemnation. It is even more unfortunate, however, that many similar, if less damaging, statements have recently been made concerning halothane another halogenated hydrocarbon inhalation anaesthetic. These have also been accompanied by an equally inappropriate lack of substantiating numerical data.

\section{The Hepatic Function Tests: 1915 to the Present}

In 1915 Whipple and Speed, ${ }^{11}$ using the excretion of intravenously administered phenoltetrachlorophthalein as an index of the functional capacity of the liver of the dog, concluded that ethyl alcohol, chloral, chloroform, diethyl ether, paraldehyde and urethane all not uncommonly produced transient changes in hepatic function. In $1922 \mathrm{La}^{\mathrm{R} o c q u \mathrm{e}^{12}}$ reached a similar conclusion after studying postoperative hepatic function in man, by means of urinary excretion of urobilin and bile pigments.

Many additional similar studies of the effects of all known anaesthetic drugs have been conducted both in the experimental animal and in man, through utilization of a wide range of hepatic function tests. ${ }^{13}$ As a result of these studies, it now appears to be "generally accepted" that transient, subclinical abnormalities in the results of the hepatic function tests commonly develop following anaesthesia and surgery. In addition, these abnormalities seem to be correlated with the magnitude of the surgical procedure, but not with the specific anaesthetic drugs administered, with the possible exception of chloroform.

In general, our understanding of this phenomenon has advanced little since Whipple and Sperry ${ }^{11}$ reached their conclusions 57 years ago. Indeed, Little ${ }^{13}$ concluded in 1970, "It seems probable that these changes in liver function represented a part of the organism's total reaction to the combined stress of surgery and mesthesia, rather than a specific toxic effect of the anesthetic agents employed."

\section{The Chloroform Centennial: 1947}

Following the condemnation of chloroform referred to above, the use of the Irug steadily declined. ${ }^{14}$ However, results of a questionnaire distributed by Gillies ${ }^{15}$ at the time of the Centennial reveal that the drug was still in widespread 
use, by both general practitioners and specialists, in the United Kingdom. Waters and his co-workers ${ }^{16}$ at Madison, Wisconsin, conducted a series of studies on the effect of this drug on the liver of both the experimental animal and man, also to commemorate the Centennial. They concluded, as indeed did Gillies, that the drug did not deserve to be abandoned.

Although a recent review of the current position of this drug ${ }^{14}$ indicates that its use has not been entirely abandoned, it is fair to state that recently the use of chloroform has obviously been highly restricted. While there is no doubt that this drug is dangerously hepatotoxic, and nephrotoxic, when ingested by humans, ${ }^{17}$ there remains a small group of individuals who believe that the drug may be used safely in the clinic, if it is administered as part of a modern anaesthetic technique. Indeed, when I had the pleasure of lecturing to a group of physician and nurse anaesthetists in Buffalo, New York, earlier this year, I was interested to find that three members of my audience were still in the habit of administering chloroform to obstetrical patients. No satisfactory large epidemiologic study of the effect of inhaled chloroform on the human liver has ever been reported. ${ }^{18,19}$

\section{ThE Cohort Studies: 1963-1969}

Sixteen years after the chloroform Centennial, another similar controversy was precipitated by the publication of a number of isolated case reports of hepatic damage following the administration of halothane. ${ }^{3}$ Fortunately, on this occasion, a group of nine retrospective cohort studies was undertaken to attempt to provide an adequate epidemiological evaluation of the problem. ${ }^{19-27} \mathrm{My}$ colleagues and I have previously reviewed the criteria by which these bona fide epidemological studies can be differentiated from the many unstructured patient series, or collections of isolated case reports, that have also been published. ${ }^{28-30}$ The criteria may be summarized thus: "(1) the exact size of the patient sample studied (the denominator) must be known; (2) a single pre-determined criterion of hepatic damage (the end-point from which the numerator is derived) must have been used; (3) there must have been an acceptable mechanism for ensuring that all patients who demonstrated this end-point were recognized (reliable surveillance as opposed to voluntary case-finding; for the purposes of this review reliable surveillance is defined as surveillance specifically noted to have been conducted by research workers who actively observed the cohorts of patients under surveillance); and (4) an appropriate control cohort must have been derived in such a manner that the surveillance mechanism was as reliable at recognizing patients who demonstrated the end-point in this cohort as it was in recognizing the same patients in the study cohort."30

The first 8 of these studies, ${ }^{19-25}$ although important, were smaller and had less impact than the ninth - the United States National Halothane Study ${ }^{26,27}$ - they encompassed an average of only 28,807 general anaesthetics apiece, and they all failed to attempt to evaluate the efficacy of halothane. Nevertheless, as shown in Tables I and II, they all "failed to provide evidence that the hepatotoxic potential of halothane was greater than that of the alternative anaesthetic agents and techniques."20 
TABLE I

Retrospective Cohort Studies: Hepatic Necrosis Discovered at Autopsy

\begin{tabular}{|c|c|c|c|}
\hline Author & Criterion & Halothane & Others \\
\hline $\begin{array}{l}\text { Slater } \\
\text { Mushin } \\
\text { Mus }\end{array}$ & $\begin{array}{l}\text { Central and massive necrosis } \\
\text { Central necrosis }\end{array}$ & $\begin{array}{l}3: 14,685 \\
0: 15,747\end{array}$ & $\begin{array}{l}7: 32,238 \\
1: 6123\end{array}$ \\
\hline Perry ${ }^{25}$ & Massive necrosis & $0: 6618$ & $0: 16,083$ \\
\hline
\end{tabular}

Source: Dykes. ${ }^{28}$ By permission of International Anesthesiology Clinics, Little, Brown \& Co.

TABLE II

Retrospective Cohort Studies: Clinical Hepatic Damage

\begin{tabular}{|c|c|c|c|}
\hline Author & Criterion & Halothane & Others \\
\hline Dawson $^{21}$ & $\begin{array}{l}\text { Unexplained deterioration; no } \\
\text { surgical cause }\end{array}$ & $3: 749$ & $4: 925$ \\
\hline $\begin{array}{l}\text { Allen20 } \\
\text { Mushin }^{24}\end{array}$ & $\begin{array}{l}\text { Unexplained complications } \\
\text { Abnormal tests; no surgical }\end{array}$ & $0: 13,024$ & $0: 7160$ \\
\hline $\begin{array}{l}\text { Henderson } \\
\text { Dykes }^{22}\end{array}$ & $\begin{array}{l}\text { cause } \\
\text { Bilirubinemia }>1.5 \mathrm{mg} / 100 \mathrm{ml} \\
\text { Acute parenchymatous disease }\end{array}$ & $\begin{array}{r}16: 15,747 \\
88: 21,461 \\
8: 14,685\end{array}$ & $\begin{array}{r}14: 6123 \\
113: 26,850 \\
10: 32,238\end{array}$ \\
\hline
\end{tabular}

Source: Dykes. ${ }^{28}$ By permission of International Anesthesiology Clinics, Little, Brown \& Co.

The United States National Halothane Study ${ }^{26,27}$ determined that the overall autopsy incidence of massive hepatic necrosis was approximately 1:10,000 for all five anaesthetic practices studied (halothane, nitrous oxide-barbiturate, cyclopropane, diethyl ether and "other"). A "blind" ad hoc panel determined that a bona fide "explanation" for the massive hepatic necrosis was present in 73 of the 82 cases. Although seven of the nine "unexplained" cases had received halothane for the final operation, this small excess of cases in the halothane cohort was believed to be explicable by the effect of volunteer bias, as six of them were known to the participating institutions before the study began. Volunteer bias may exist when institutions are invited or volunteer to participate in a study partly because they have observed patients who demonstrated the condition to be studied. It is of interest that the number of "explained" cases of massive hepatic necrosis following halothane (19), is smaller than the number of expected cases (23.7). The latter figure equals the product of the total number of massive hepatic necrosis cases $(82)$ and the total number of deaths following the agent $(4,863)$, divided by the total number of deaths $(16,840)$. This discrepancy has never been satisfactorily explained.

This large study attempted to evaluate the efficacy of halothane by comparing the standardized in-hospital death rates following the five anaesthetic practices, and concluded "Halothane, rather than being a dangerous anesthetic, had a record of safety...." ${ }^{27}$ The death rate data derived in this study also indicated that the differences in death rates between the 34 institutions that participated in the study, were much greater than differences between the anaesthetics, and that "the overall death rate problem is of an order of magnitude larger in its implications for patient care than that of massive hepatic necrosis." 27 It must be stressed, however, 
that this study was retrospective, and that the authors themselves warned of the problem of volunteer bias, and also stated "These results must be interpreted with caution for two reasons. First, the lack of randomization and the fact that only 60 per cent of the deaths were necropsied completely are certain to introduce biases. Second, there are so few actual cases that the analysis could neither estimate these biases nor hope to correct for them."26

\section{Multiple Halothane Administrations: 1968 to the Present}

The evidence relating to the effect of multiple halothane administrations upon the human liver will be presented in four sections.

\section{Unstructured patient series}

In 1968 Little, ${ }^{31}$ Klatskin, ${ }^{32}$ and Trey et al. ${ }^{33}$ each published evidence upon which a most tentative hypothesis was advanced, that multiple halothane administrations might be particularly hazardous for the liver. This evidence, and additional similar material published since 1968, has been thoroughly reviewed and evaluated. ${ }^{29,30,34}$ There is little doubt that an anxious medical profession has interpreted this evidence in an uncritical manner, and has drawn unwarranted conclusions therefrom, as none of the material "was designed to provide epidemiologic data aimed at testing the hypothesis that hepatic damage is more common after multiple administrations of halothane."30

\section{Repeated halothane administrations}

A series of individual patients, each of whom received several administrations of halothane without demonstrating evidence of hepatic dysfunction, has been reported. ${ }^{34}$ One of these patients received 89 administrations of the drug over a four-year period. ${ }^{35}$ This group of patients appears to constitute proof that multiple administrations of halothane do not necessarily damage the liver.

Two small series of patients who received multiple administrations of halothane for radiotherapy for carcinoma of the cervix, ${ }^{36}$ and for burn therapy, ${ }^{37}$ respectively, have provided contradictory evidence. The former, which tends to incriminate halothane, is subject to criticism on several points, ${ }^{30}$ and the latter, which tends to exonerate halothane, although the larger of the two studies encompasses insufficient patients to be conclusive.

\section{Cohort study}

Table III depicts the only epidemiological data in the medical literature which is helpful when an anaesthetic has to be chosen for a patient who has received halothane in the past. These data relate to the 80,600 patients from the United States National Halothane Study, ${ }^{26,27}$ who received two or more general anaesthetics in the same or successive months, and as such are subject to the qualifications concerning this study that were noted above. In addition, it must be stressed that of the 10 patients who developed massive hepatic necrosis after multiple 
TABLE III

United States National Halothane Study: Postoperative Massive Hepatic Necrosis and Crude Overall Postoperative DEATH Rates PER 10,000

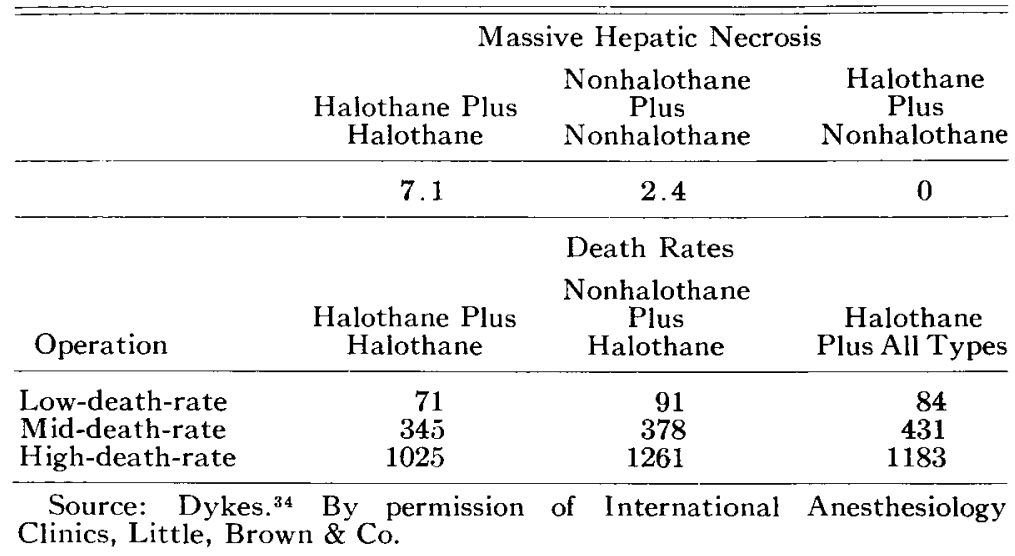

administrations of halothane, only four were judged by the ad hoc panel as being "unexplained," and of these, three were known to the participating institutions before the study began. Table III indicates that multiple administrations of halothane may be associated with a higher incidence of massive hepatic necrosis, but a lower overall death rate, than one halothane and one non-halothane anaesthetic. Because of the various biases inherent in this retrospective study, however, this material can only be considered to be hypothesis formulating evidence. No study exists which proves that multiple administrations of halothane are followed by a higher incidence of hepatitis than either single administrations of halothane or multiple administrations of other anaesthetics.

\section{Challenge}

Twelve patients have now been reported in the medical literature, who have demonstrated a positive anaesthetic challenge with halothane - two separate episodes of hepatic dysfunction following two separate exposures to halothane for the purpose of producing clinical anaesthesia. These patients can be accepted as suggesting strongly that "halothane hepatitis" exists. ${ }^{29,30,34}$ The only truly compelling evidence for the existence of this specific disease - hepatitis caused by halothane in the same sense that tuberculous meningitis means meningitis caused by tuberculosis - is the existence of two anaesthetists who demonstrated positive true challenges with halothane, ${ }^{38,39}$ and a laboratory technician who demonstrated a strongly presumptive positive environmental challenge with the $\mathrm{drug}^{40} \mathrm{~A}$ positive true challenge occurs when an individual develops hepatic dysfunction following a deliberate administration of halothane, and a positive environmental challenge occurs when an individual develops two separate episodes of hepatic dysfunction following two separate occupational exposures to extremely low (pollutant) concentrations of the drug. 


\section{The Present}

I will now review the current position of four important controversial issues concerning the effect of halothane on the liver.

\section{Incidence of "halothane hepatitis"}

The incidence of "halothane hepatitis" during the period studied by United States National Halothane Study (1958-1962), was estimated to be no greater than $1: 10,000 .{ }^{18}$ This was presumably because that was the approximate combined incidence of "explained" and "unexplained" massive hepatic necrosis following the administration of halothane in the Study. ${ }^{26,27}$ It should be noted, however, that the incidences in the Study of "unexplained" massive hepatic necrosis following single and multiple administrations of halothane were 0.27:10,000 and 2.8:10,000 respectively. It must be stressed that these figures can only be accepted as very rough estimates of the incidences of fatal "halothane hepatitis," because of the many biases involved in their derivation. ${ }^{29}$ In addition, the fact that no numerical data currently exist relating to the ratio of non-fatal to fatal "halothane hepatitis" must render any attempt to estimate the true incidence of the entity grossly inaccurate. Finally, it is interesting that only one member ${ }^{39}$ of a total American Society of Anesthesiologists membership of approximately 10,000 has apparently been proved to have demonstrated a bona fide hepatic sensitization reaction to halothane.

Perhaps it is fair to say that "halothane hepatitis" is rare. In so doing, however, one opens oneself to the indirect criticism that Bleich has recently aimed at the verbal description of certain prognostic criteria, specifically that with the use of quantitative data rather than the use of adjectives and adverbs, "medicine took a large step forward." 41

\section{Pathologic features of "halothane hepatitis"}

Chalmers, in his Presidential Address to the American Gastroenterological Association in 1969, emphasized "the need for a detailed description in each paper of the techniques employed to control bias ("blinding") in the gathering of subjective morphological data." 42 He further noted that in the case of electron microscopists "the danger of bias is greatest of all because a potentially meaningless chance observation can be preserved by a photograph," and "the combined effects of extreme magnification and universal biological variability should make it possible for an investigator to find what he is after if he looks hard enough for it."

The only attempt to describe a specific pathologic picture for "halothane hepatitis," while remaining "blind" to the anaesthetic history of the patients, was made by the six man Pathology Panel of the United States National Halothane Study. ${ }^{26}$ This panel was unable to describe any consistent specific histologic picture following exposure to halothane.

\section{Diagnosis of "halothane hepatitis"}

Two paths have been taken by physicians who have attempted to establish the diagnosis of "halothane hepatitis" in the individual patient. First, in instances when hepatitis has developed following the administration of halothane in the 
absence of other known causal factors, the following argument has been presented. Because it is too much of a coincidence for this disease to be unexplained viral hepatitis, it must be "halothane hepatitis." This argument - the epidemiologically "clean" case approach - is unacceptable for the following reasons. Based on Koff" $s^{43}$ figures for the incidences in the United States of viral hepatitis (mainly infectious hepatitis), complete reporting, and anicteric to icteric cases, of approximately 20 cases per 100,000 population, 10 per cent, and one to one respectively, then 400 cases of the disease per 100,000 population might be expected. Assuming the possibility that approximately 10 million patients in the United States receive halothane in any one year, ${ }^{18}$ and an average incubation period for viral hepatitis (mainly infectious hepatitis) of five weeks, then approximately 4000 patients can be expected to receive halothane during the incubation period of the disease in any one year in the United States. I must stress that this is a tentative figure that could be substantially in error in either direction. At least, however, it establishes an approximate numerical value for an important clinical problem that no one appears to have attempted to quantify until recently. ${ }^{18,29}$ In addition, the Boston Inter-Hospital Liver Group ${ }^{44-46}$ has determined that approximately two-thirds of a group of patients with viral hepatitis were unable to recall any overtly recognizable source of infection - that is, they had contracted "unexplained" viral hepatitis. Also, it appears from recent immunologic studies that viral hepatitis is much more common in the United States than previously suspected. Lander et al. have recently discovered high incidences of antibodies to the hepatitis antigen (anti-HAA) of 14.4 per cent in voluntary blood donors, ${ }^{47}$ and of 20 per cent in randomly selected patients admitted to Children's Hospital and District of Columbia General Hospital, Washington, D.C. ${ }^{48}$ These authors commented, "The high frequency of anti-HAA in persons with no history of hepatitis or parenteral exposure to blood suggests that HAA-positive hepatitis is endemic in the United States and that it is transmitted by a non-parenteral route," 47 and "the hepatitis virus, whether causing overt or subclinical disease, is more widespread than previously thought." 48 Finally, the epidemiologically "clean" case approach has been proved to be totally inadequate by the instances where it has been used to diagnose "halothane hepatitis" in patients who never received halothane!

Physicians taking the second path diagnose "halothane hepatitis" only when an individual patient has been subjected to either a true, an environmental or an anaesthetic challenge. A review of the illnesses presented by the patients in the literature who have been so challenged, ${ }^{18,34}$ indicates that they suffered from a non-specific hepatitis that is indistinguishable from viral hepatitis on clinical, biochemical and pathologic grounds.

I would recommend strongly that patients who develop unexplained hepatitis following administration of halothane, and who have not demonstrated a positive challenge test, should be diagnosed only as suffering from "unexplained hepatitis associated with the administration of halothane." On the basis of "the usual medical doctrine that any treatment followed by ill effects should ordinarily not be repeated,"27 however, the recommendation of the United States National Halothane Study ${ }^{26,27}$ that such patients should not receive halothane again appears reasonable.

I do not believe that these two recommendations are incompatible, and as such 
are inconsistent with sound medical practice. In fact, I do believe that any other course of action would be inconsistent with sound scientific practice, and I choose to support my position by quoting from three authorities. Spodick has noted that "the history of medicine continues to reveal that very little is either simple or obvious and that we must ask for convincing proof," 49 and Weed has stated that "A diagnosis is a step forward only when it can be sustained by the evidence at hand."50 Finally, Pickering has noted that it is difficult to be both a physician and a scientist, and has commented "Intellectual nihilism is the very stuff of which scientists are made, but it is scarcely convenient for a practicing physician."51 In the present context as scientists it will not be possible for us to make the diagnosis of "halothane hepatitis" in the individual patient until a clinically useful specific, and hopefully sensitive, diagnostic test becomes available. In the interim, however, as physicians we will be expected to treat (anaesthetize) to the best of our ability, any patients requiring anaesthesia who have developed "unexplained hepatitis" following a previous administration of halothane.

\section{Prognostic test for "halothane hepatitis"}

The clinical dilemma produced by the existence of "halothane hepatitis," and the emotional and medicolegal climate that surrounds the entity, would be solved if a test could be derived that would indicate accurately which patients had been sensitized by the drug and which had not. It is unfortunate that "unexplained postoperative fever" following administration of halothane seems to have become generally accepted to be an indication that the patient has become sensitized to the drug. No acceptable epidemiologic studies of this possible prognostic test have been conducted, and I have determined that temperature clevations are almost universal following all but the least traumatic surgical procedures, and are not uncommon following essentially atraumatic surgical procedures. ${ }^{52}$

In 1970 Paronetto and Popper formulated the hypothesis that "stimulation of lymphocytes in the presence of halothane is helpful in the differential diagnosis of viral and halothane hepatitis." 53 Bruce and Raymon ${ }^{54}$ have recently described a healthy male anaesthesiologist who demonstrated a positive halothane lymphocyte stimulation test, but a negative true halothane challenge similar to the one reported by Klatskin and Kimberg. ${ }^{39}$ In commenting upon this interesting finding, Paronetto and Popper stress their belief that the halothane lymphocyte stimulation test has "no value as far as predicting the patients at risk," but suggested again that the test "may be of help in the differential diagnosis between viral and halothane hepatitis." The extent to which this test will help in differentiating between these two currently indistinguishable discases, will, of course, depend upon a careful numerical evaluation of its specificity (incidence of false positives) and sensitivity (incidence of false negatives). Until this precise biostatistical work has been accomplished, it is impossible to evaluate the usefulness of any diagnostic or prognostic test.

\section{Conclusions}

The only truly compelling evidence for the existence of "halothane hepatitis" remains the two anaesthesists who demonstrated positive true challenges, and the 
laboratory technician who demonstrated a strongly presumptive positive challenge to pollutant concentrations of halothane. An acceptable epidemiological study has not as yet been reported which indicates that the hepatotoxicity of halothane is greater than that of the alternative drugs.

The incidence of "halothane hepatitis" remains unknown, and no specific pathological or other diagnostic features have been described which reliably differentiate the disease from viral hepatitis. In addition, there is also currently no reliable prognostic test for detecting the patient who has been sensitized to the drug.

In the absence of a reliable method of differentiating "halothane hepatitis" and viral hepatitis, only a large randomized clinical trial will illuminate the relative incidence of the two diseases in post-operative patients.

\section{RÉSUMÉ}

Ce travail va se limiter à l'étude des effets toxiques des anesthésiques sur le foie humain in vivo. Ces effets peuvent être classifiés comme des réactions médicamenteuses indésirables et peuvent être évaluées alors seulement par l'évaluation simultanée de l'efficacité et de la toxicité des agents en question. Etant donné que de telles évaluations ne peuvent être faites que chez des humains malades, elle relèvent des techniques d'enquête de l'épidémiologiste. La stratégie de l'épidémiologie a été classifiée par MacMahon et ass. comme suit :

(1) L'épidémiologie descriptive

(2) La formulation de l'hypothèse

(3) L'épidémiologie analytique, (a) les études de l'histoire du cas (affecté vs non affecté) (b) les études de contact (exposés ou non exposés) et

(4) L'épidémiologie expérimentale (les essais cliniques).

\section{Les années passées et les tests de la fonction hépatique}

Les premiers cas de dommage hépatique clinique après l'anesthésie semblent avoir été rapportés en 1848, mais des études contrôlées de ce phénomène n'ont pas été entreprises avant plusieurs années. Toutefois, il existe actuellement une quantité substantielle de travaux concernant l'effet des divers agents et techniques anesthésiques sur le foie évalué par l'usage des tests de la fonction hépatique post opératoire. La première étude de ce genre chez l'humain a été faite en 1922. Il semble, comme résultats de ces tests, qu'il apparait assez souvent des anomalies transitoires et subcliniques; ces anomalies seraient proportionnelles à l'importance de l'agression chirurgicale mais non attribuables à un agent ou une technique anesthésique spécifique. Malheureusement, les tests utilisés ne sont pas des tests spécifiques de la fonction hépatique et il n'est pas certain non plus que les anomalies signalées représentent une dysfonction hépatique ou encore lequel de plusieurs autres facteurs autres que les agents eux-mêmes peut avoir entrainé de telles anomalies.

\section{Le centenaire du chloroforme et les études en masse}

Une étude faite au moment du centenaire du chloroforme a indiqué que cet agent n'étais pas entièrement abandonné et, en conséquence, la controverse n'avait 
jamais été résolue de façon satisfaisante. L'hypothèse que l'halothane pouvait être hépatotoxique a été émise en 1.963 à la suite de la publication de plusieurs cas isolés. Contrairement à l'attitude prise en réponse à la controverse du rhloroforme, la controverse de l'halothane a déclanché de nontreuses études rétrospectives. Entre 1963 et 1965, huit études de ce genre ont été publiées; trois ont utilisé le terme précis, objectif de nécrose hépatique découverte à l'autopsie et cinq autres ont employé plusieurs termes moins sévères, non mortels et survenant plus fréquemment. Ces études qui étaient destinées à évaluer la toxicité de l'halothane et non son efficacité, “ont toutes échoué à prouver que le potentiel hépatotoxıque de l'halothane était plus grand que ceux des autres agents et techniques anesthésiques".

L'étude nationale de l'halothane résumée en 1966 et publiée sous sa forme finale en 1969 est la seule étude où il y a eu une tentative d'évaluer à la fois l'efficacité et la toxicité du médicament. Cette étude non plus n’a pas réussi à prouver qu'une seule administration d'halothane était suivie d'une plus grande fréquence de nécrose hépatique massive qu'une seule administration d'aucun des quatre autres agents étudiés. Les taux normaux de mortalité à l'hôpital à la suite de l'étude des cinq agents anesthésiques étudiés - l'évaluation de l'efficacité faite ont indiqué que l'halothane, et à un moindre degré le protoxyde d'azote et les barbituriques, étaient suivis des taux les plus bas. Toutefois, il ne faut pas assumer que les différences entre les taux n'avaient comme agent causal que les différents agents anesthésiques.

De plus, cette étude a montré que les différences entre les taux de mortalité entre les 34 institutions qui ont pris part à l'étude étaient substantiellement plus grandes qu'entre les agents anesthésiques même après un ajustement des variantes connues entrant en jeu; l'étude a montré en plus que le problème des taux généraux de mortalité, en termes d'impact sur les soins aux malades, étaient plus grands que celui de la nécrose hépatique massive.

\section{Administrations multiples de Phalothane}

L'étude nationale de l'halothane contenait également des données qui laissaient entendre que plusieurs anesthésies - deux ou plus de deux anesthésies générales dans le même mois ou au cours de mois successifs - s'accompagnaient d'une augmentation de la fréquence des morts aussi bien que de la nécrose hépatique massive. La fréquence de la nécrose s'élevait davantage à la suite de multiples administrations d'halothane, alors que le mortalité semblait diminuer à la suite de deux anesthésies à l'halothane, en comparaison avec une anesthésie à l'halothane suivie d'une anesthésie sans halothane. "Il existe donc une possibilité, alors, que si l'on administre une deuxième anesthésie à l'halothane au malade qui en a reçu une antérieurement, les possibilités d'une complication rare fatale sont beaucoup plus grandes - nécrose hépatique massive - mais elle peuvent être compensées par une diminution notable d'une issue plus fréquente - la mort."

La réalite de l'entité "hépatite à l'halothane" actuellement ne fait plus de doute à cause de la documentation de son existence par de vrais tests positifs dans deux anesthésies. De plus, de nombreux malades auraient souffert de troubles hépatiques à la suite de deux administrations séparées d'halothane. On peut considérer ces malades comme des défis positifs à l'agent. Bien que l'existence de l'entité soit 
connue, il n'existe pas de données statistiques qui démontrent sa fréquence et il n'existe pas de techniques qui permettent de faire le diagnostic chez un malade particulier, car cette maladie ne peut pas être différentiée d'une autre maladie mal définie - l'hépatite virale. Pour des fins académiques, l'usage de malades comme tests est évidemment contre l'éthique. De plus, il n'existe pas de test permettant d'identifier le malade qui est devenu sensibilisé à l'halothane. Une fièvre postopératoire qui demeure sans explication après une première administration du médicament, ce qui avait été considéré comme un signe important, se rencontre tellement souvent que "cela ne peut pas nécessairement constituer une contraindication à l'usage subséquent du médicament chez le malade."

Bien que nous connaissions beaucoup de choses sur la toxicité hépatique des anesthésiques, il reste beaucoup d'hypothèses à vérifier. Les épidémiologies de l'hépatotoxicité du chloroforme lorsqu'il était employé comme agent anesthésique et de celle de l'halothane demeurent tout à fait inconnues et il faut espérer que cette situation peu satisfaisante ne se perpétuera pas indéfiniment.

\section{REFERENCES}

I. MacMahon, B., Pugh, T.F., \& Ipsen, J. Epidemiologic methods. Boston: Little, Brown \& Co $(1960)$.

2. MacMahon, B. \& Pugh, T.F. Epidemiology, principles and methods. Boston: Little, Brown \& Co (1970).

3. Dykes, M.H.M. The early years: 1846-1912. In Anesthesia and the liver, edited by by M.H.M. Dykes, Boston: Little, Brown \& Co (1970).

4. Defalque, R.J. The first delayed chloroform poisoning. Anesth. \& Analg. 47: 374 (1968).

5. Simpson, J.Y. On the anesthetic and sedative properties of bichloride of carbon, or chlorocarbon. Med. Times Gazette 2: 651 (1865).

6. HARDIN, B.L. Carbon tetrachloride poisoning. A review. Indust. Med. Surg. 23: 93 (1954).

7. Bevan, A.D. \& Favill, H.B. Acid intoxication and late poisonous effects of anesthetics. Hepatic toxemia, acute fatty degeneration of the liver following chloroform and ether anesthesia. J.A.M.A. 45: 691 \& 754 (1905).

8. Hown.AND, J. \& Richands, A.N. An experimental study of the metabolism and pathology of delayed chloroform poisoning. J. Exp. Med. 11:344 (1909).

9. Whipple, G.H. \& SPERry, J.A. Chloroform poisoning. Liver necrosis and repair. Bull. Johns Hopkins Hosp. 20: 278 (1909).

10. Henderson, Y., Cullen, T.S., Martin, E.D., Huntington, T.W., \& Murphy, F.T. Report of Committee on Anesthesia of the American Medical Association. J.A.M.A. 58: 1908 (1912).

11. Whipple, G.H. \& SPEed, J.S. Liver function as influenced by anesthetics and narcotics. J. Exp. Med. 21: 203 (1915).

12. La Roceve, C. The effects of general anaesthetics on the liver. Canada. Med. Ass. J. 12: 566 (1922).

13. Litrte, D.M. Postoperative Hepatic Function Tests, In Anesthesia and the Liver, edited by M.H.M. Dykes, Boston: Little, Brown \& Co (1970).

14. Armstrong Davison, M.H. \& WYnne, N.A. Chloroform since 1912. In Anesthesia and the Liver, edited by M.H.M. Dykes, Boston: Little, Brown \& Co (1970).

15. Gillies, J. Analysis of replies to a questionary on the use of chloroform at the present time. Anaesthesia 3: 45 (1948).

16. WATERs, R.M. Chloroform: A Study after 100 years. Madison: University of Wisconsin (1951).

17. Dykes, M.H.M. Halogenated hydrocarbon ingestion. In Anesthesia and the Liver, edited by H.M.H. Dykes, Boston: Little, Brown \& Co (1970).

18. Dykes, H.M.H. \& Bunker, J.P. Hepatotoxicity and anesthetics. Pharm. for Physicians 4: 1 (Nov. 1970). 
19. Slater, E.M., Gibson, J.M., Dykes, M.H.M., \& Walzer, S.G. Postoperative hepatic necrosis. Its incidence and diagnostic value in association with the administration of halothane. New Eng. J. Med. 270: 983 (1964).

20. Allen, H.L. \& Metcalf, D.W. A search for halothane liver complications. Anesth. \& Analg. 43: 159 ( 1964 ).

21. Dawson, B., Jones, R.R., Schnelle, N., Hartridge, V.B., Paulson, J.A., Adson, M.A., \& Summenskill, W.H.J. Halothane and ether anesthesia in gallbladder and bile duct surgery. A retrospective study into mortality and hepatobiliary complications. Anesth. \& Analg. 42: 759 (1963).

22. Dykes, M.H.M., Walzer, S.G., Slater, E.M., Gibson, J.M., \& Ellis, D.S. Acute parenchymatous hepatic disease following general anesthesia. Clinical appraisal of hepatotoxicity following administration of halothane. J.A.M.A. 193: 339 (1965).

23. Henderson, J.C. \& Gordon, R.A. The incidence of postoperative jaundice with special reference to halothane. Canad. Anaesth. Soc. I. 11:453 (1964).

24. Mushin, W.W., Rosen, M., Bowen, D.J., \& Camprell, H. Halothane and liver dysfunction. A retrospective study. Brit. Med. J. 2: 329 (1964).

25. Perry, L.B. \& Jenicek, J.A. Massive hepatic necrosis associated with general anesthesia. Milit. Med. 129: 1148 (1964).

26. Bunker, J.P., Forrest, W.H., Mosteller, F., \& Vandam, L.D. The National Halothane Study. A Study of the Possible Association between Halothane Anesthesia and Postoperative Hepatic Necrosis, Washington: U.S. Government Printing Office (1969).

27. Subcommittee on the National Halothane Stady of the Committee on Anesthesia, National Academy of Sciences - National Research Council. Summary of the National Halothane Study. Possible Association between Halothane Anesthesia and Postoperative Hepatic Necrosis. J.A.M.A. 197: 775 (1966).

28. Dykfs, M.H.M. Hepatotoxicity of Anesthetic Agents. In Anesthesia and the Liver, edited by M.H.M. Dykes, Boston: Little, Brown \& Co (1970).

29. Dykes, M.H.M., Gribert, J.P., Schur, P.H., \& Cohen, E.N. Halothane and the Liver. A Review of the Epidemiologic, Immunologic and Metabolic Aspects of the Relationship. Canad. J. Surg. 15: 217 (1972).

30. Dykes, M.H.M., Gribert, J.P., \& McPeek, B. Halothane in the United States. An appraisal of the "halothane hepatitis" literature and the American reaction to it. Brit. J. Anaesth. 44: 925 ( 1972).

31. Littre, D.M. Effects of halothane on hepatic function. In Halothane, edited by N.M. Greene, Philadelphia: Davis (1968).

32. Klatskin, G. Introduction mechanisms of toxic and drug-induced hepatic injury. In: Toxicity of anesthetics, edited by R. Fink, Baltimore: Williams \& Wilkins (1968).

33. Trey, C., Lipworth, L., Chalmers, T.C., Davidson, C.S., Gottilieb, L.S., Popper, H., \& SAunders, S. Fulminant hepatic failure. Presumable contribution of halothane. New Eng. J. Med. 279: 798 (1968).

34. Dykes, M.H.M. Multiple halothane administrations. In Anesthesia and the Liver, edited by M.H.M. Dykes, Boston: Little, Brown \& Co (1970).

35. Anwan, J.E. A record number of anaesthetics? A case report. Brit. J. Anaesth. $42: 736$ (1970).

36. Hughes, M. \& Powert, L.W. Recurrent hepatitis in patients receiving multiple halothane anaesthetics for radium treatment of carcinoma of the cervix uteri. Gastroenterology 58 : $790(1970)$.

37. Gronert, G.A., Schaner, P.J. \& Gunther, R.C. Multiple halothane anesthesia in the burn patient. J.A.M.A. 205: 878 (1968).

38. Belfrage, S., Ahlgren, I., \& Axelson, S. Halothane hepatitis in anaesthetists. Lancet 2: 1466 ( 1966 ).

39. Klatskin, G. \& Kimberg, D.V. Recurrent hepatitis attributable to halothane sensitization in an anesthetist. New Eng. J. Med. 280: 515 (1969).

40. Johnston, C.I. \& Mendelsohn, F. Halothane hepatitis in a laboratory technician. Aust. N.Z. J. Med. $1: 171$ ( 1971 ).

41. Bleich, H.L. Prognosis by calculation. New Eng. J. Med. 285: 1533 ( 1971 ).

42. Chalamers, T.C. A challenge to clinical investigators. Gastroenterology 57: 631 (1969).

43. Koff, R.S. Postoperative hepatic dysfunction, In Anesthesia and the liver, edited by M.H.M. Dykes. Boston: Little, Brown \& Co (1970).

44. Grady, G.F., Chalmers, T.C., \& The Boston Inter-Hospital Liver Group. Viral hepatitis in a group of Boston hospitals. I. A retrospective study of 1675 patients. New Eng. J. Med. 272: 657 (1965). 
45. Grady, G.F., Chalmers, T.C., \& The Boston Inter-Hospital Liver Group. Viral hepatitis in a group of Boston hospitals. II. A prospective controlled epidemiologic study. New Eng. J. Med. 272: 662 (1965).

46. Koff, R.S., Grady, G.F., Chalmers, T.C., Mosley, J.W., Swartz, B.C., \& The Boston Inter-Hospital Liver Group. Viral hepatitis in a group of Boston hospitals. III. Importance of exposure to shellfish in a nonepidemic period. New Eng. J. Med. 276: 703 (1967).

47. Lander, J.J., Alter, H.J., \& Purcell, R.H. Frequency of antibody to hepatitis-associated antigen as measured by a new radioimmunoassay technique. J. Immunol. 106: 1116 (1971).

48. Lander, J.J., Holland, P.V., Alter, H.J., Chanock, R.M., \& Purcell, R.H. Antibody to hepatitis-associated antigen. Frequency and pattern of response as detected by radioimmunoprecipitation. J.A.M.A. 220: 1079 (1972).

49. Spodrck, D.H. Revascularization of the heart-numerators in search of denominators. Am. Heart J. 81 : 149 ( 1971 ).

50. WeED, L.L. Medical records that guide and teach. New Eng. J. Med. 278: $593 \& 652$ (1968).

51. Pickering, G. Physician and scientist. Brit. Med. J. 2: 1615 (1964).

52. Dykes, M.H.M. Unexplained postoperative fever. Its value as a sign of halothane sensitization. J.A.M.A. 216: 641 (1971).

53. Paronetto, F. \& Popper, H. Lymphocyte stimulation induced by halothane in patients with hepatitis following exposure to halothane. New Eng. J. Med. 283: 277 (1970).

54. Bruce, D.L. \& Raymon, F. Test for halothane sensitivity. New Eng. J. Med. 286: 1218 (1972).

55. Paronetto, F. \& Popper, H. Test for halothane sensitivity. New Eng. J. Med. $286: 1218$ (1972). 